\title{
Letter from the Editors
}

Before you lies the first issue of 2012. In true Itinerario spirit, it contains a great variety of articles which not only vary by region - from Africa to East Asia-but also in time, from the early modern period to the modern era. In a fascinating article by Matthew Mitchell, the role of the fetish in intercultural trade on the African coast is explored, with particular attention for the way European merchants contributed to the creation of local rituals of trade. The article by Roger Knight engages the current vibrant debate on race and class in Dutch colonial society by examining the life stories of a number of nineteenth-century female migrants to the East Indies. The mid-twentieth-century strategies for coping with famines in Portuguese Cape Verde, and societal effects thereof, form the main concern of Alexander Keese's article "Managing the Prospect of Famine." And Gerrit de Graaf's article takes us to the world of missionaries in Papua New Guinea in the 1950s and 60s, examining both their expectations and the reality of religious conversion. Finally, we are happy to include an archival note from Lennart Bes, in which he introduces students and scholars to the holdings of fabulous and unknown Dutch sources in Asia. The review section, put together by our tireless colleague Laura Cruz, concludes this issue.

While this issue was being processed the biannual conference of FEEGI was hosted by the Early Modern History Center at the University of Minnesota, Minneapolis. Some of our editors were lucky enough to attend this event, and were unanimous in their opinion that it was a stimulating and fruitful experience, due to the great variety of topics and intimate atmosphere. Indeed, it felt like entering a living issue of Itinerario! Our next issue will include a more extensive report of the conference. In the meantime, we invite you to enjoy the fascinating articles in this issue.

The Editors 